\title{
Geno- and cytotoxicity induced on Cyprinus carpio by aluminum, iron, mercury and mixture thereof
}

\author{
Leobardo Manuel Gómez-Oliván ${ }^{\text {a,*, }}$, Youssef Paolo Mendoza-Zenil ${ }^{a}$, Nely SanJuan-Reyes ${ }^{\text {a }}$,

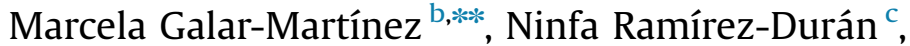 \\ Rosa del Carmen Rodríguez Martín-Doimeadios ${ }^{\mathrm{d}}$, Nuria Rodríguez-Fariñas ${ }^{\mathrm{d}}$, \\ Hariz Islas-Flores a , Armando Elizalde-Velázquez a , Sandra García-Medina ${ }^{\text {b }}$, \\ Ricardo Pérez-Pastén Borja ${ }^{\mathrm{b}}$

\footnotetext{
${ }^{a}$ Laboratorio de Toxicología Ambiental, Facultad de Química, Universidad Autónoma del Estado de México, Paseo Colón intersección Paseo Tollocan s/n. Col Residencial Colón, 50120 Toluca, Estado de México, Mexico

b Laboratorio de Toxicología Acuática, Departamento de Farmacia, Escuela Nacional de Ciencias Biológicas, Instituto Politécnico Nacional, Unidad Profesional Adolfo López Mateos, Av. Wilfrido Massieu s/n y Cerrada de Manuel Stampa, Col. Industrial Vallejo, C.P. 007700 México, D.F., Mexico

${ }^{\mathrm{c}}$ Laboratorio de Microbiología Médica y Ambiental de la Facultad de Medicina, Universidad Autónoma del Estado de México, Paseo Tollocan y Venustiano Carranza s/n. Col. Universidad, 50180 Toluca, Estado de México, Mexico

d Departamento de Química Analítica y Tecnología de los Alimentos, Facultad de Ciencias Ambientales y Bioquímica, Universidad de Castilla-La Mancha,
} \\ Avenida Carlos III s/n, E-45071 Toledo, Spain
}

\section{A R T I C L E I N F O}

\section{Article history:}

Received 4 July 2016

Received in revised form

29 September 2016

Accepted 30 September 2016

Available online 7 October 2016

\section{Keywords:}

Heavy metals

DNA damage

Apoptosis

\begin{abstract}
A B S T R A C T
Metals such as $\mathrm{Al}$, Fe and $\mathrm{Hg}$ are used in diverse anthropogenic activities. Their presence in water bodies is due mainly to domestic, agricultural and industrial wastewater discharges and constitutes a hazard for the organisms inhabiting these environments. The present study aimed to evaluate geno- and cytotoxicity induced by $\mathrm{Al}, \mathrm{Fe}, \mathrm{Hg}$ and the mixture of these metals on blood of the common carp Cyprinus carpio. Specimens were exposed to the permissible limits in water for human use and consumption according to the pertinent official Mexican norm [official Mexican norm NOM-127-SSA1-1994] Al $\left(0.2 \mathrm{mg} \mathrm{L}^{-1}\right)$, $\mathrm{Fe}\left(0.3 \mathrm{mg} \mathrm{L}^{-1}\right), \mathrm{Hg}\left(0.001 \mathrm{mg} \mathrm{L}^{-1}\right)$ and their mixture for $12,24,48,72$ and $96 \mathrm{~h}$. Biomarkers of genotoxicity (comet assay and micronucleus test) and cytotoxicity (caspase- 3 activity and TUNEL assay) were evaluated. Significant increases relative to the control group $(p<0.05)$ were observed in all biomarkers at all exposure times in all test systems; however, damage was greater when the metals were present as a mixture. Furthermore, correlations between metal concentrations and biomarkers of geno- and cytotoxicity were found only at certain exposure times. In conclusion, $\mathrm{Al}, \mathrm{Fe}, \mathrm{Hg}$ and the mixture of these metals induce geno- and cytotoxicity on blood of C. carpio.
\end{abstract}

(c) 2016 Elsevier Inc. All rights reserved.

\section{Introduction}

Chemical contaminants reach water bodies through diverse sources of exposure. The relevance of heavy metal studies resides in the characteristics of these elements: high toxicity and persistence, and rapid bioaccumulation by aquatic organisms (Cervantes

\footnotetext{
Abbreviations: AAS/AES, atomic absorption/emission spectrophotometry; ICP-MS, inductively coupled plasma-mass spectrometry; MeHg, methylmercury; $\mathrm{MNi}$, micronuclei; TUNEL, terminal deoxynucleotidyl transferase-mediated dUTP nick-end labeling; pNA, p-nitroaniline; ROS, reactive oxygen species; SEM, standard error of the mean

* Corresponding author.

** Corresponding author.

E-mail addresses: lmgomezo@uaemex.mx, lgolivan74@gmail.com (L.M. Gómez-Oliván), mgalarm@ipn.mx (M. Galar-Martínez).
}

and Moreno, 2010; Rosas, 2001).

A heavy metal is any metallic element having a relative high density and toxicity even at very low concentrations. Such metals include $\mathrm{Al}$, $\mathrm{Fe}$ and $\mathrm{Hg}$, among others (Lucho-Constantino et al., 2005). Aluminum is one of the most abundant metals in Earth's crust and is used in diverse anthropogenic activities (GarcíaMedina et al., 2010). Iron is a micronutrient; it is essential for all living organisms and plays a major role in vital biochemical activities such as oxygen transport to tissue, electron transfer, and catalysis (Aisen et al., 2001; Pérez et al., 2005). It is also involved in DNA synthesis and is a component part of hemoglobin, myoglobin, cytochromes and diverse enzymes (Huang et al., 2015). Iron is naturally present in ground and surface water. In aquatic ecosystems, $\mathrm{Hg}$ presence results mainly from its atmospheric deposition due to anthropogenic activities (Chan et al., 2003; Morel et al., 
1998; Pacyna and Pacyna, 2002). In water, inorganic Hg is transformed by bacterial action to methylmercury (MeHg), a highly toxic compound which accumulates in sediment (Chan et al., 2003; Driscoll et al., 2007; Morel et al., 1998; Ullrich et al., 2001).

Heavy metals enter the aquatic ecosystem through hospital, municipal and industrial residues which are discharged without prior treatment, resulting in the presence of high concentrations (Costa et al., 2015; Fernández-Dávila et al., 2012; García and Dorronsoro, 2005; Kim et al., 2013).

In Mexico, research on the environmental occurrence of this type of contaminants includes studies by Avila-Pérez et al. (1999), who detected $\mathrm{Fe}\left(880-33080 \mathrm{mg} \mathrm{L}^{-1}\right)$ and $\mathrm{Hg}\left(17-181 \mathrm{mg} \mathrm{L}^{-1}\right)$, among other metals, in surface water and the water column of José Antonio Alzate Reservoir, in the State of Mexico. In Aguascalientes, $\mathrm{Al}$ and Fe concentrations were measured in the Río San Pedro, concentrations of $0.06-62.60$ and $1.04-22.60 \mathrm{mg} \mathrm{L}^{-1}$ respectively were detected (Guzmán et al., 2010). The presence of Fe (1.09$1.80 \mathrm{mg} \mathrm{L}^{-1}$ ) has been reported in Río Chihuahua water (Gutiérrez et al., 2008), while in the State of Mexico Al (6.04-24.45 $\mathrm{mg} \mathrm{L}^{-1}$ ), Fe $\left(1.37-5.10 \mathrm{mg} \mathrm{L}^{-1}\right)$ and $\mathrm{Hg}\left(<0.001 \mathrm{mg} \mathrm{L}^{-1}\right)$ were found in Madín Dam (González-González et al., 2014), and $\mathrm{Hg}$ (0.021 $\left.\mathrm{mg} \mathrm{L}^{-1}\right)$ was detected in wastewater from a public hospital (Neri-Cruz et al., 2015).

The constant release of contaminants into the aquatic ecosystem implies the presence of a mixture of these. Trace amounts or minimum quantities of metals can have positive or negative effects on aquatic organisms. Slight variations in their concentrations, decreases as well as increases, can have toxic consequences on aquatic organisms (Wittmann, 1981). In fish, Al is neurotoxic; it induces gill damage due to increased mucus production which affects osmoregulation and respiration (Exley et al., 1997; Ward et al., 2006), causing hypoxia, hypercapnia, metabolic acidosis and eventually respiratory insufficiency (Allin and Wilson, 2000; Røyset et al., 2005). Furthermore, it elicits diverse hematological changes (Bhagwant and Bhikajee, 2000; García-Medina et al., 2010). While Fe has diverse biological functions, at high concentrations this metal may induce DNA damage, hemochromatosis and carcinogenesis (Huang, 2004; Mello-Filho and Meneghini, 1991), the principal organs so damaged being the heart, liver and endocrine glands (Italia et al., 2015). In fish, the main damage induced by $\mathrm{Hg}$ is at the central nervous system level (Berntssen et al., 2003).

Several studies have shown that exposure to contaminants, including heavy metals, stimulates ROS (reactive oxygen species) production in the cell (Li et al., 2006; Sinha et al., 2007), contributing to oxidative stress generation and, consequently, DNA damage. Metallic ions interact with cellular components such as nuclear proteins and DNA, inducing DNA damage and conformational changes which may lead to cell cycle modulation, carcinogenesis or apoptosis (Beyersmann and Hartwig, 2008; Chang et al., 1996; Wang and Shi, 2001).

Fish are used as sensitive indicators of genotoxic and mutagenic changes since they bioaccumulate contaminants present in water (Yadav and Trivedi, 2009) and their response to chemical exposure is similar to response in higher vertebrates (Al-Sabti, 1991). The common carp Cyprinus carpio is a commercial species which, due to its economic importance and wide geographic distribution, has been proposed as a test aquatic organism in toxicological assays (De Boeck et al., 2007; Oruç and Usta, 2007). In Mexico, this species is consumed by humans and is frequently cultured in water bodies contaminated with diverse xenobiotics including heavy metals.

Therefore, the aim of the present study was to evaluate the geno- and cytotoxicity induced by $\mathrm{Al}, \mathrm{Fe}, \mathrm{Hg}$ and the mixture of these metals on blood of $C$. carpio.

\section{Materials and methods}

\subsection{Specimen procurement and maintenance}

Common carp (Cyprinus carpio) specimens were obtained from the aquaculture facility in Tiacaque (State of Mexico). Polyethylene bags containing water and oxygen were used to transport the fish to the Environmental Toxicology Laboratory at the Department of Chemistry (Universidad Autónoma del Estado de México). Carp were maintained for a 15-d acclimation period in 160-L fish tanks (a fish for each two liters of water was placed) with synthetic culture medium ( $\mathrm{pH}$ 7.4), at room temperature, with constant aeration and a 12:12 h light/dark photoperiod, and were fed Pedregal Silver ${ }^{\mathrm{TM}}$ fish food.

\subsection{Experimental design}

Specimens $20.15 \pm 0.28 \mathrm{~cm}$ long and weighing $55.67 \pm 6.2 \mathrm{~g}$ were maintained under conditions similar to those used for acclimation. To test systems with six carp each was added $\mathrm{Al}$ (0.2 $\left.\mathrm{mg} \mathrm{L}^{-1}\right)$, Fe $\left(0.3 \mathrm{mg} \mathrm{L}^{-1}\right)$ or $\mathrm{Hg}\left(0.001 \mathrm{mg} \mathrm{L}^{-1}\right)$ according to the permissible limits in water for human use and consumption in the official Mexican norm (NOM-127-SSA1-1994). The assay also included a test system to which was added the mixture of all three metals at the same concentrations, as well as a control system. Exposure times were 12, 24, 48, 72 and 96 h. Static systems were used without renewal of test solution. The assay was performed in triplicate, using a total of 450 fish. At the end of the exposure time, carp were removed from the systems and placed in a fish tank containing a xylocaine solution $\left(0.02 \mathrm{mg} \mathrm{mL}^{-1}\right.$, AztraZeneca, Naucalpan, State of Mexico), to anesthetize them prior to collecting a blood sample $(2 \mathrm{~mL})$ from the caudal vein, using a heparinized 2-mL hypodermic syringe.

\subsubsection{Comet assay}

The procedure proposed by Tice et al. (2000) was used. Previously prepared microscope slides were used to obtain the sample. Frosted slides were covered with $200 \mu \mathrm{L}$ of $1 \%$ agarose (SigmaAldrich, St Louis, MO) and maintained at room temperature until dry. Whole blood samples $(10 \mu \mathrm{L})$ were mixed with $75 \mu \mathrm{L}$ of $0.7 \%$ agarose (Sigma-Aldrich, St Louis), and $50 \mu \mathrm{L}$ of this mixture was spread on the initial agarose layer and solidified on ice. The slides were placed inside a Coplin jar with lysis solution $[2.5 \mathrm{M} \mathrm{NaCl}$, 100 mM EDTA, 10 mM Tris (all Sigma-Aldrich, Toluca, Mexico), 10\% dimethyl sulfoxide (DMSO, J.T. Baker, Center Valley, PA) and $1 \%$ Triton X-100 (Sigma-Aldrich, St Louis)] pH 10, for $1 \mathrm{~h}$ at $4{ }^{\circ} \mathrm{C}$. The slides were then placed in the electrophoresis chamber with alkaline solution [300 mM NaOH and 1 mM EDTA (both Sigma-Aldrich, Toluca)] at $\mathrm{pH} 13$ for $20 \mathrm{~min}$. Electrophoresis was performed at $300 \mathrm{~mA}$ and $25 \mathrm{~V}\left(4^{\circ} \mathrm{C}, 20 \mathrm{~min}\right.$, field strength: $\left.0.8 \mathrm{~V} / \mathrm{cm}\right)$ and was halted with a neutralization buffer [0.4 M Trizma base (SigmaAldrich, St Louis) pH 7.4]. The DNA was stained with $50 \mu \mathrm{L}$ ethidium bromide (10 $\mathrm{mg} \mathrm{mL}^{-1}$; Sigma-Aldrich, St Louis) and examined in an epifluorescence microscope (Motic BA410) equipped with a Moticam Pro CCD digital camera.

\subsubsection{Micronucleus test}

Whole blood from each specimen was fixed with pure ethanol (Mallinckrodt Baker, State of Mexico) on a slide for $5 \mathrm{~min}$, then stained with $10 \%$ Giemsa (Hycel, Mexico City, Mexico) for 9 min. A light microscope was used to examine a total of 1000 cells per sample. Results were expressed as the total number of micronucleated cells per 1000 cells (Çavaş and Ergene-Gözükara, 2005). 
were cultured in RPMI-1640 medium containing 10\% fetal bovine serum in a humidified, $5 \% \mathrm{CO}_{2}$ atmosphere at $37^{\circ} \mathrm{C}$, as recommended by ATCC. Cell density was initially adjusted to $10^{6}$ cells $\mathrm{mL}^{-1}$, and anti-Fas $\mathrm{mAb}\left(50 \mathrm{ng} \mathrm{mL}^{-1}\right.$, MBL International) was added to the cells as a positive (apoptosis inducer) control. To inhibited apoptosis samples was added $125 \mu \mathrm{L}$ of the inhibitor Z-VAD-FMK (carbobenzoxy-valyl-alanyl-aspartyl-(O-methyl)fluoromethylketone, $20 \mathrm{mM}$ ) at the same time as the anti-Fas $\mathrm{mAb}$. The samples were incubated overnight for $16 \mathrm{~h}$ at $37^{\circ} \mathrm{C}$ in a humidified, $5 \% \mathrm{CO}_{2}$ atmosphere, then centrifuged at $450 \mathrm{~g}$ and $4{ }^{\circ} \mathrm{C}$ for $10 \mathrm{~min}$, and the cells were harvested. The cell pellet was maintained on ice, washed with cold phosphate-buffered saline (PBS) and resuspended in cell lysis buffer. The final cell concentration was $10^{8}$ cells $\mathrm{mL}^{-1}$. Cells were lysed by freeze-thaw, then incubated on ice for $15 \mathrm{~min}$. The cell lysate was centrifuged at $15,000 \mathrm{~g}$ and $4{ }^{\circ} \mathrm{C}$ for $20 \mathrm{~min}$, and the supernatant was collected.

2.2.3.2. Colorimetric assay. A CaspACEтM colorimetric assay kit (Promega, Madison, WI) and an UltraCruz ${ }^{\mathrm{TM}}$ microplate with flatbottom wells were used. The blank was prepared white reaction mixture [32 $\mu \mathrm{L}$ caspase buffer (312.5 Mm HEPES pH 7.5, 31.25\% saccharose, $0.3125 \%$ CHAPS (3-[(3-cholamidopropyl)dimethylammonio]-1-propane-sulfonate)), $2 \mu \mathrm{L}$ DMSO, $10 \mu \mathrm{L}$ dithiothreitol (DTT, $100 \mathrm{mM}$ )] and $54 \mu \mathrm{L}$ deionized water. For the control group and groups exposed to $\mathrm{Al}, \mathrm{Fe}, \mathrm{Hg}$ or the mixture, the following were used: reaction mixture, $20 \mu \mathrm{L}$ blood and $54 \mu \mathrm{L}$ deionized water; for the positive control and for inhibited apoptosis samples: reaction mixture, $20 \mu \mathrm{L}$ cellular extract and $34 \mu \mathrm{L}$ deionized water. After all solutions had been transferred, $2 \mu \mathrm{L}$ of substrate DEVD-pNA was added to each well. The microplate was covered with parafilm and incubated for $4 \mathrm{~h}$ at $37^{\circ} \mathrm{C}$. Absorbance was read at $405 \mathrm{~nm}$ and the specific activity of caspase- 3 was calculated. Results were expressed as nM free $\mathrm{pNAh}^{-1} \mu \mathrm{g}^{-1}$ protein. Total protein content was determined by the Bradford (1976) method.

\subsubsection{Determination of total protein content}

To $25 \mu \mathrm{L}$ of supernatant was added $75 \mu \mathrm{L}$ deionized water and $2.5 \mathrm{~mL}$ Bradford's reagent [0.05 g Coomassie blue (Sigma-Aldrich, Toluca), $25 \mathrm{~mL}$ of $96 \%$ ethanol (Sigma-Aldrich, Toluca) and $50 \mathrm{~mL} \mathrm{H}_{3} \mathrm{PO}_{4}$ (Vetec, Mexico City) in $500 \mathrm{~mL}$ deionized water]. The tubes were shaken and allowed to rest for $5 \mathrm{~min}$ prior to reading absorbance at $595 \mathrm{~nm}$. Results were interpolated onto a standard bovine serum albumin curve.

\subsubsection{TUNEL assay}

The ApopTag S7110 fluorescein kit (Chemicon, Temecula, CA) was used. Whole blood samples $(300 \mu \mathrm{L})$ were centrifuged at $800 \mathrm{~g}$ and $4{ }^{\circ} \mathrm{C}$ for $5 \mathrm{~min}$; the cell pellet was resuspended with $50 \mu \mathrm{L}$ of the mounting medium and $1 \mu \mathrm{L}$ of cells was placed on a slide with poly-L-lysine (Sigma-Aldrich, St Louis), dried at $60{ }^{\circ} \mathrm{C}$ for $5 \mathrm{~min}$, fixed in cold acetone for $10 \mathrm{~min}$, and hydrated in successive changes (from 100\% to 50\%) of xylene, ethanol (both Mallinckrodt Baker) and water. The cells were treated with proteinase $\mathrm{K}$ (20 $\mu \mathrm{g} \mathrm{mL}^{-1}$, Fluka-Sigma-Aldrich, Toluca) for $10 \mathrm{~min}$, then washed with PBS ( $\mathrm{NaCl} 0.138 \mathrm{M}, \mathrm{KCl} 0.0027 \mathrm{M}$, Sigma-Aldrich, Toluca) $\mathrm{pH}$ 7.4. Next, $60 \mu \mathrm{L}$ equilibrium buffer was added, followed by incubation with $65 \mu \mathrm{L}$ TdT enzyme for $60 \mathrm{~min}$ at $37^{\circ} \mathrm{C}$. The cells were washed with PBS prior to adding the anti-FITC conjugate that was used as a cell marker, then maintained at room temperature for $30 \mathrm{~min}$, washed with PBS, stained with propidium iodide (1.5 $\mu \mathrm{L} \mathrm{mL}^{-1}$, Sigma-Aldrich, St Louis) and examined in the epifluorescence microscope with digital camera. The negative control sample consisted of cells treated as described but without addition of Tdt, while the positive control sample consisted of cells treated with DNase I ( $1 \mu \mathrm{L} \mathrm{mL}^{-1}$, Sigma-Aldrich, St Louis). A total of 100 cells were examined per specimen, and apoptosis was expressed as the percentage of TUNEL-positive cells per 100 cells.

\subsection{Determining concentrations of $\mathrm{Al}, \mathrm{Fe}, \mathrm{Hg}$ and mixture thereof}

Whole blood samples $(0.2-0.4 \mathrm{~mL})$ were digested with $8 \mathrm{~mL}$ $\mathrm{HNO}_{3}$ (65\% Suprapur-grade) and $2 \mathrm{~mL} \mathrm{H}_{2} \mathrm{O}_{2}$ (30\% v/v Suprapurgrade, Merck Millipore, Barcelona, Spain) in a Milestone Ethos Plus microwave oven (Monroe, CT) for $10 \mathrm{~min}$ at $180^{\circ} \mathrm{C}$ after $15-\mathrm{min}$ ramping. Digested samples were diluted with $4 \mathrm{~mL}$ ultrapure water $(18.2 \mathrm{M} \Omega \mathrm{cm})$ and refrigerated until analysis. The total $\mathrm{Al}$ and total $\mathrm{Hg}$ analyses were performed by inductively coupled plasma-mass spectrometry (ICP-MS) using a Thermo Electron XSeries II system with collision cell technology (CCT), operated in standard mode to obtain data on ${ }^{27} \mathrm{Al}$ and ${ }^{202} \mathrm{Hg}$. Iron was analyzed by atomic absorption/emission spectrophotometry (AAS/AES) using a Varian SpectraAA 50 system equipped with air-acetylene flame and a hollow-cathode lamp. Detection limits $\left(\mu \mathrm{g} \mathrm{L}^{-1}\right)$ were: Al 1.185, $\mathrm{Hg} 0.058$, and Fe 0.016. Quantification limits $\left(\mu \mathrm{g} \mathrm{L}^{-1}\right)$

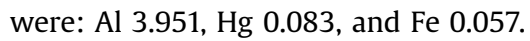

As reference materials, muscle and liver of dogfish were analyzed; the percentage of recovery in muscle was $95.9 \pm 9.2 \%$ for $\mathrm{Al}$, $102.3 \pm 7.5 \%$ for $\mathrm{Hg}$ and $92.9 \pm 2.9 \%$ for $\mathrm{Fe}$, while in liver it was $95.4 \pm 12.4 \%$ for $\mathrm{Al}, 102.4 \pm 24.2 \%$ for $\mathrm{Hg}$ and $106.2 \pm 6.2 \%$ for Fe.

\subsection{Statistical analysis}

Results were statistically evaluated by one-way analysis of variance (ANOVA). Data normality and homoscedasticity were verified by Shapiro-Wilk and Levene tests, respectively. The Bonferroni post hoc test was used to evaluate significant differences, with $p$ set at $<0.05$. Pearson's correlation analysis was performed to find potential correlations of concentrations of $\mathrm{Al}, \mathrm{Fe}, \mathrm{Hg}$ and the mixture with biomarkers of geno- and cytotoxicity. Sigmastat v2.03 was used.

Table 1

Concentrations of $\mathrm{Al}, \mathrm{Fe}, \mathrm{Hg}$ and mixture thereof in blood of $\mathrm{C}$. carpio.

\begin{tabular}{|c|c|c|c|c|c|}
\hline Metals & $12 \mathrm{~h}$ & $24 \mathrm{~h}$ & $48 \mathrm{~h}$ & $72 \mathrm{~h}$ & $96 \mathrm{~h}$ \\
\hline $\begin{array}{l}\mathrm{Al}\left(\mathrm{mg} \mathrm{L}^{-1}\right) \\
\mathrm{Fe}\left(\mathrm{mg} \mathrm{L}^{-1}\right) \\
\mathrm{Hg}\left(\mathrm{mg} \mathrm{L}^{-1}\right)\end{array}$ & $\begin{array}{l}0.153 \pm 6 \times 10^{-3^{*}, \mathrm{~b}, \mathrm{c}, \mathrm{d}, \mathrm{e}} \\
0.03 \pm 2 \times 10^{-4 \mathrm{~b}, \mathrm{c}, \mathrm{d}, \mathrm{e}} \\
0.00014 \pm 5 \times 10^{-5^{*}}\end{array}$ & $\begin{array}{l}0.129 \pm 6 \times 10^{-3^{*}, \mathrm{a}, \mathrm{c}, \mathrm{d}, \mathrm{e}} \\
0.01 \pm 5 \times 10^{-4 \mathrm{a}, \mathrm{d}, \mathrm{e}} \\
0.00017 \pm 6 \times 10^{-6}\end{array}$ & $\begin{array}{l}0.137 \pm 4 \times 10^{-3^{*}, \mathrm{a}, \mathrm{b}, \mathrm{d}, \mathrm{e}} \\
0.01 \pm 5 \times 10^{-4 \mathrm{a}, \mathrm{d}, \mathrm{e}} \\
0.00024 \pm 1 \times 10^{-6^{*}}\end{array}$ & $\begin{array}{l}0.186 \pm 9 \times 10^{-3^{*}, \mathrm{a}, \mathrm{b}, \mathrm{c}, \mathrm{e}} \\
0.02 \pm 5 \times 10^{-4 \mathrm{a}, \mathrm{b}, \mathrm{c}, \mathrm{e}} \\
0.00017 \pm 9 \times 10^{-6^{*}}\end{array}$ & $\begin{array}{l}0.0729 \pm 8 \times 10^{-4^{*}, \mathrm{a}, \mathrm{b}, \mathrm{c}, \mathrm{d}} \\
0.04 \pm 1 \times 10^{-4^{*}, \mathrm{a}, \mathrm{b}, \mathrm{c}, \mathrm{d}} \\
0.00015 \pm 1 \times 10^{-5^{*}}\end{array}$ \\
\hline $\begin{array}{l}\text { Mixture } \\
\mathrm{Al}\left(\mathrm{mg} \mathrm{L}^{-1}\right) \\
\mathrm{Fe}\left(\mathrm{mg} \mathrm{L}^{-1}\right) \\
\mathrm{Hg}\left(\mathrm{mg} \mathrm{L}^{-1}\right)\end{array}$ & $\begin{array}{l}0.100 \pm 7 \times 10^{-3 b, c, d, e} \\
0.03 \pm 4 \times 10^{-5 b, c, d, e} \\
0.0003 \pm 1 \times 10^{-6 c, e}\end{array}$ & $\begin{array}{l}0.0415 \pm 3 \times 10^{-4 a, c, d, e} \\
0.01 \pm 3 \times 10^{-4 a, c, d, e} \\
0.00014 \pm 1 \times 10^{-6 c, d, e}\end{array}$ & $\begin{array}{l}0.0643 \pm 7 \times 10^{-4 a, b, d, e} \\
0.01 \pm 3 \times 10^{-4 a, b, d} \\
0.0008 \pm 9 \times 10^{-6 a, b}\end{array}$ & $\begin{array}{l}0.0597 \pm 3 \times 10^{-4 a, b, c, e} \\
0.02 \pm 5 \times 10^{-4 a, b, c} \\
0.0005 \pm 1 \times 10^{-6 b}\end{array}$ & $\begin{array}{l}0.0519 \pm 3 \times 10^{-4 a, b, c, d} \\
0.02 \pm 3 \times 10^{-4 a, b} \\
0.0007 \pm 4 \times 10^{-6 a, b}\end{array}$ \\
\hline
\end{tabular}

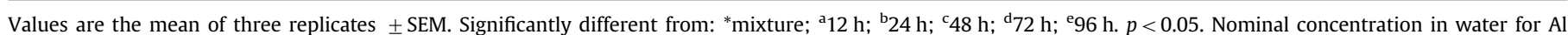
(0.2 $\left.\mathrm{mg} \mathrm{L}^{-1}\right)$, Fe $\left(0.3 \mathrm{mg} \mathrm{L}^{-1}\right)$ and $\mathrm{Hg}\left(0.001 \mathrm{mg} \mathrm{L}^{-1}\right)$. 


\section{Results and discussion}

Anthropogenic activity has resulted in the presence of high concentrations of heavy metals in water bodies, soil and air (Andreu et al., 2016). In Mexico, the concentrations of $\mathrm{Al}$, $\mathrm{Fe}$ and $\mathrm{Hg}$ detected in diverse water bodies exceed the maximum permissible limits in the official norm on water for human use and consumption (NOM-127-SSA1-1994).

Heavy metal distribution and transport in water depends on the presence of species of these metals in the water column as well as on their environmental availability (González-González et al., 2014). After entering the body, these contaminants are transported in the blood to the different organs and tissues where they bioaccumulate since they are not metabolized. Table 1 shows the concentration of $\mathrm{Al}\left(0.0729-0.186 \mathrm{mg} \mathrm{L}^{-1}\right)$, Fe (0.01$\left.0.04 \mathrm{mg} \mathrm{L}^{-1}\right), \mathrm{Hg}\left(0.00014-0.00024 \mathrm{mg} \mathrm{L}^{-1}\right)$ and the mixture [Al $\left(0.0415-0.1 \mathrm{mg} \mathrm{L}^{-1}\right) ; \quad$ Fe $\quad\left(0.01-0.03 \mathrm{mg} \mathrm{L}^{-1}\right) ; \quad \mathrm{Hg} \quad(0.00014$ $\left.\left.0.0008 \mathrm{mg} \mathrm{L}^{-1}\right)\right]$ in blood of $C$. carpio exposed for $12,24,48,72$ and $96 \mathrm{~h}$. In mixtures of contaminants with diverse specific modes of action, may occur interactions and the changes are basically modifications in the concentration of the contaminants. Heavy metals can alter physiologic and biochemical parameters in blood and tissue of fish (Vinodhini and Narayanan, 2009). Damage to DNA has been proposed as a useful biomarker for evaluating the

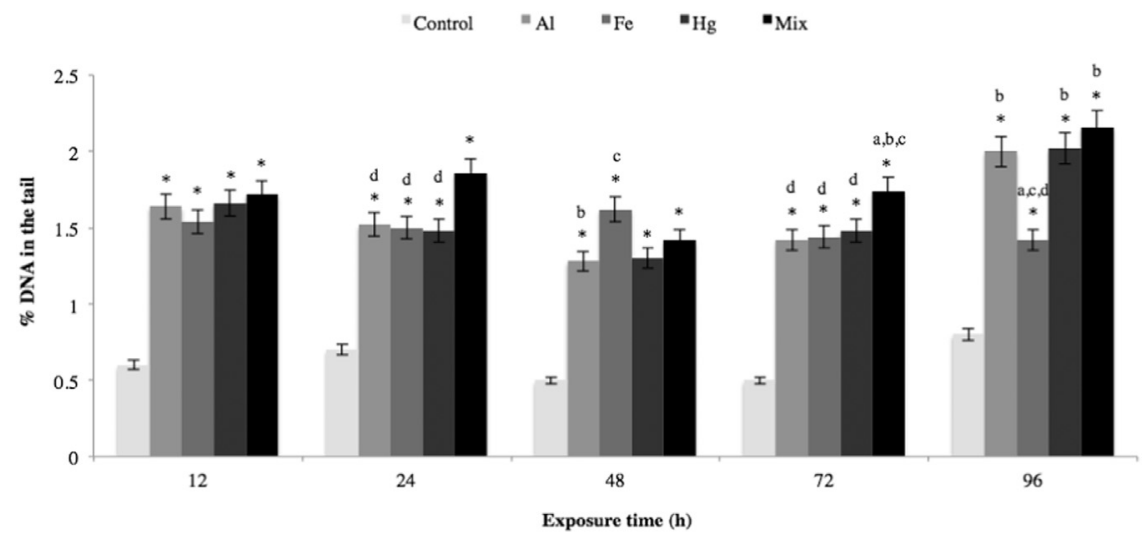

Fig. 1. Comet assay determination of DNA damage in blood of C. carpio exposed to Al, Fe, $\mathrm{Hg}$ and mixture thereof for 12, 24, 48, 72 and $96 \mathrm{~h}$. Values are the mean of three replicates \pm SEM. Significantly different from: *control group; ${ }^{\mathrm{A}} \mathrm{Al}$; ${ }^{\mathrm{b}} \mathrm{Fe}$; ${ }^{\mathrm{C} g} \mathrm{H} ;{ }^{\mathrm{d}} \mathrm{Mix}$. (Bonferroni post hoc, $p<0.05$ ).

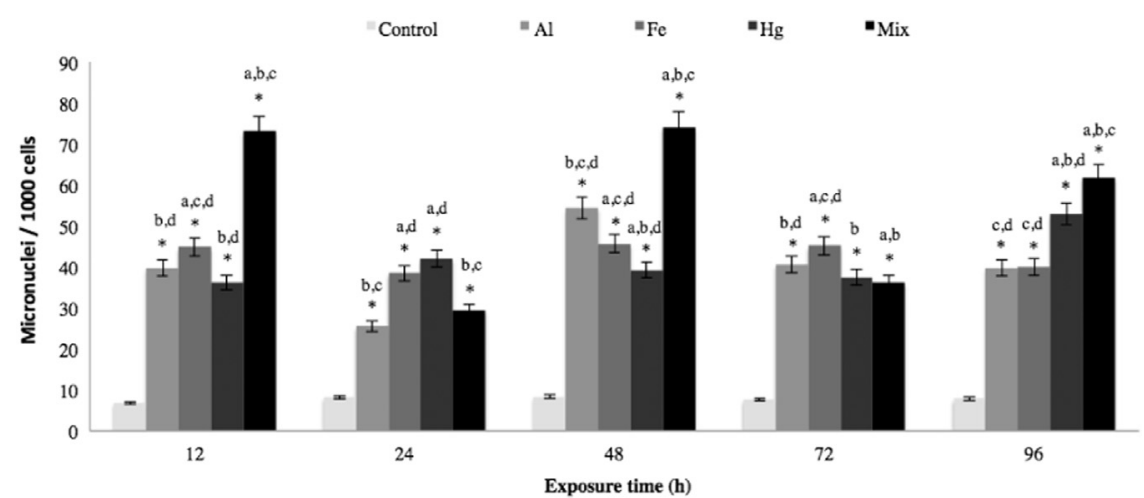

Fig. 2. Frequency of micronuclei in blood of $C$. carpio exposed to $\mathrm{Al}, \mathrm{Fe}, \mathrm{Hg}$ and mixture thereof for $12,24,48,72$ and $96 \mathrm{~h}$. Values are the mean of three replicates $\pm \mathrm{SEM}$. Significantly different from: ${ }^{*}$ control group; ${ }^{\mathrm{a}} \mathrm{Al} ;{ }^{\mathrm{b}} \mathrm{Fe} ;{ }^{\mathrm{c}} \mathrm{Hg}$; ${ }^{\mathrm{d}} \mathrm{Mix}$. (Bonferroni post hoc, $p<0.05$ ).

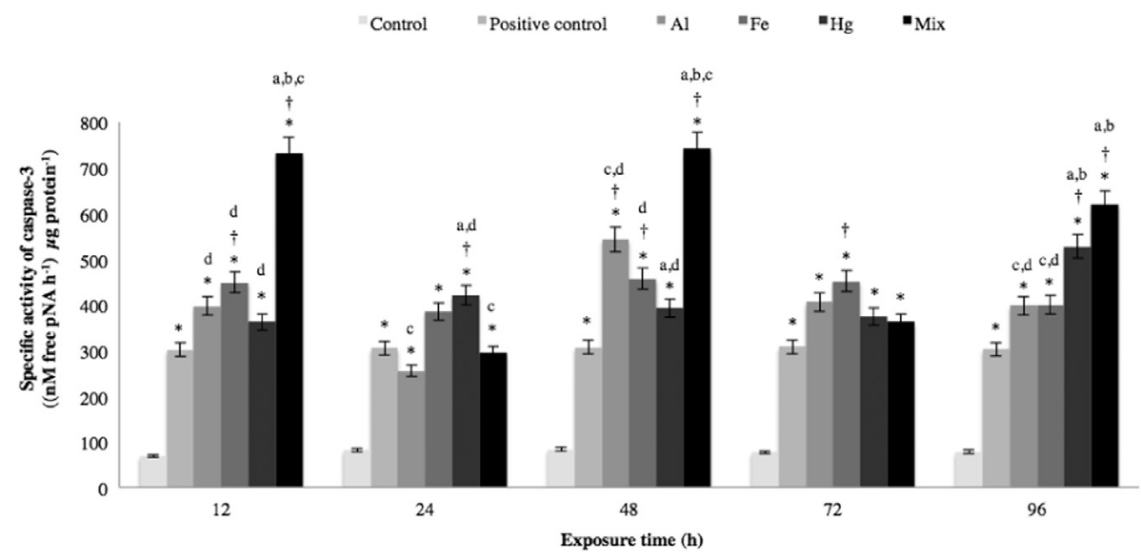

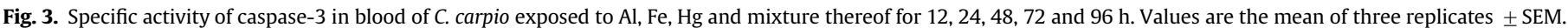
Significantly different from: *control group; ${ }^{\dagger}$ positive control; ${ }^{\mathrm{a}} \mathrm{Al}$; ${ }^{\mathrm{b}} \mathrm{Fe}$; ${ }^{\mathrm{c}} \mathrm{Hg}$; ${ }^{\mathrm{d}} \mathrm{Mix}$. (Bonferroni post hoc, $p<0.05$ ). 


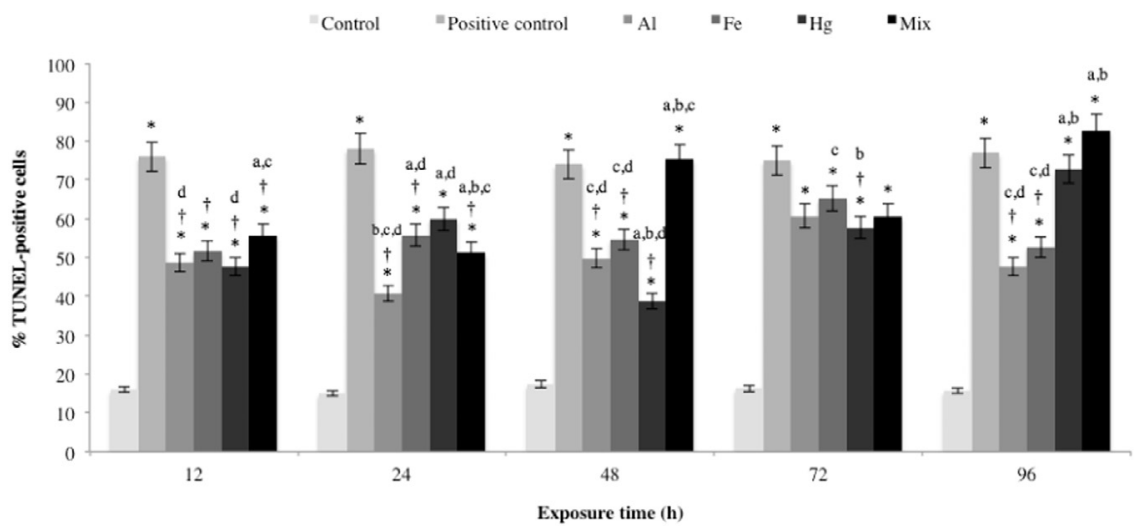

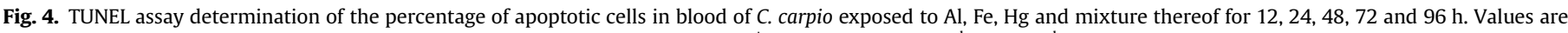
the mean of three replicates \pm SEM. Significantly different from: ${ }^{*}$ control group; ${ }^{\dagger}$ positive control; ${ }^{\mathrm{a}} \mathrm{Al}$; ${ }^{\mathrm{b}} \mathrm{Fe} ;{ }^{\mathrm{c}} \mathrm{Hg}$; ${ }^{\mathrm{d}} \mathrm{Mix}$. (Bonferroni post hoc, $p<0.05$ ).

Table 2

Pearson's correlation analysis of metal concentrations (Al, Fe, $\mathrm{Hg}$ and mixture thereof) with biomarkers of geno- and cytotoxicity in blood of $C$. carpio.

\begin{tabular}{|c|c|c|c|c|c|c|c|}
\hline \multirow[t]{2}{*}{ Biomarkers } & \multirow[t]{2}{*}{ Time (h) } & \multicolumn{6}{|l|}{ Metals } \\
\hline & & $\mathrm{Al}$ & $\mathrm{Fe}$ & $\mathrm{Hg}$ & Al (mixture) & Fe (mixture) & $\mathrm{Hg}$ (mixture) \\
\hline \multirow[t]{5}{*}{ Comet assay } & 12 & -0.671 & 0.468 & -0.823 & -0.209 & 0.395 & -0.189 \\
\hline & 24 & 0.142 & 0.645 & 0.492 & 0.306 & 0.792 & 0.753 \\
\hline & 48 & -0.217 & 0.873 & -0.698 & -0.343 & 0.052 & 0.462 \\
\hline & 72 & 0.506 & -0.753 & -0.165 & -0.594 & 0.431 & -0.508 \\
\hline & 96 & 0.274 & -0.218 & 0.099 & 0.509 & 0.662 & 0.385 \\
\hline \multirow[t]{5}{*}{ Micronucleus test } & 12 & 0.165 & -0.308 & -0.412 & 0.829 & 0.408 & -0.625 \\
\hline & 24 & 0.044 & -0.327 & -0.025 & -0.314 & -0.836 & -0.793 \\
\hline & 48 & -0.946 & -0.560 & 0.020 & 0.153 & 0.209 & -0.229 \\
\hline & 72 & -0.932 & 0.827 & -0.078 & -0.319 & 0.039 & -0.121 \\
\hline & 96 & -0.818 & -0.456 & 0.829 & -0.332 & -0.754 & -0.536 \\
\hline \multirow[t]{5}{*}{ Caspase-3 activity } & 12 & 0.273 & 0.719 & 0.387 & 0.293 & 0.023 & -0.137 \\
\hline & 24 & -0.461 & 0.859 & 0.625 & -0.853 & -0.354 & -0.475 \\
\hline & 48 & -0.439 & -0.019 & -0.129 & -0.679 & -0.359 & 0.654 \\
\hline & 72 & -0.693 & -0.309 & -0.006 & -0.656 & 0.536 & -0.609 \\
\hline & 96 & 0.012 & 0.168 & -0.160 & -0.884 & -0.919 & -0.156 \\
\hline \multirow[t]{5}{*}{ TUNEL assay } & 12 & -0.945 & 0.189 & -0.826 & -0.569 & 0.189 & 0.073 \\
\hline & 24 & 1.000 & -0.945 & 0.327 & 0.923 & 0.277 & 0.442 \\
\hline & 48 & -0.821 & -0.693 & -0.997 & 0.929 & 0.756 & -0.987 \\
\hline & 72 & 0.722 & 0.945 & -0.881 & -0.412 & 0.918 & -0.839 \\
\hline & 96 & 0.934 & 0.756 & 0.899 & -0.487 & -0.803 & -0.727 \\
\hline
\end{tabular}

Correlation coefficients $>0.5$ are statistically significant (shown in bold).

genotoxicity of environmental contaminants in biomonitoring studies (Bombail et al., 2001), these contaminants include heavy metals. The alkaline comet assay is a reliable and sensitive early biomarker of genotoxicity in aquatic organisms since it detects DNA branch migration caused by strand breaks, alkali-labile sites and transient repair sites (Frenzilli et al., 2009; Kadam et al., 2013; Møller, 2006; Villarini et al., 2011).

As can be seen in Fig. 1, DNA damage increased significantly with each of the metals as well as the mixture in comparison to the control group $(p<0.05)$. This is probably explained by the fact that by products of normal mitochondrial metabolism and homeostasis include the buildup of potentially damaging levels of ROS (Zorov et al., 2014), in addition, MeHg also induces production of these species (Farina et al., 2013) that can induce intracellular Fe release (Flint et al., 1993; Halliwell and Aruoma, 1991). The superoxide anion $\left(\mathrm{O}_{2} \bullet\right)$ releases Fe from ferritin (Bolann and Ulvik, 1990; Halliwell and Gutteridge, 1990) while hydrogen peroxide $\left(\mathrm{H}_{2} \mathrm{O}_{2}\right)$ releases Fe from hemoproteins (Gutteridge, 1986; Halliwell and Gutteridge, 1990). Via the Fenton reaction, this metal produces the hydroxyl radical $(\mathrm{OH} \bullet)$ which is highly reactive and binds to DNA bases, forming adducts (Valko et al., 2005). Aluminum itself can displace Fe in diverse biomolecules and increase intracellular
Fe levels, thus promoting the Fenton reaction (Amador et al., 2001; Dua and Gill, 2001; Yousef, 2004). This metal can also damage the mitochondrion and affect electron transport in the respiratory chain (Bondy and Campbell, 2001; García-Medina et al., 2010), increasing ROS production and thereby inducing genotoxicity. In mixture, Fe concentration did not increase, this may be explained by the fact that, free Fe can be buffered by a specific ferritin, which has an important physiological role as an antioxidant (Campanella et al., 2009; Santambrogio et al., 2007).

The main damage induced on DNA includes DNA base and sugar damage, protein-DNA and DNA-DNA crosslinks, single- and double-strand breaks, and abasic site formation (Bolognesi and Cirillo, 2014; Medeiros, 2008).

Micronuclei (MNi) are chromatin masses which form from chromosomal fragments or intact whole chromosomes and appear as small nuclei within the cytoplasm of cells in interphase (Cavas et al., 2005). Fig. 2 shows MNi frequencies in our study. Significant increases $(p<0.05)$ occurred at all exposure times and in all test systems (Al, Fe, Hg and the mixture). Such increases may be due to chromosomal breakage which yields acentric fragments, a resultant event of the clastogenic effects induced by some xenobiotics (Samanta and Dey, 2012), including metals. 
These genotoxicity results are consistent with those of other authors. García-Medina et al. (2011, 2013) reported DNA damage and higher $\mathrm{MNi}$ frequencies in $\mathrm{C}$. carpio exposed to $\mathrm{Al}(0.05,120$ and $239 \mathrm{mg} \mathrm{L}^{-1}$ ), while Yadav and Trivedi (2009) concluded that exposure to $\mathrm{Hg}\left(0.081 \mathrm{mg} \mathrm{L}^{-1}\right)$ induces MNi formation in Channa punctata. Similarly, Bolognesi et al. (1999) found that $\mathrm{Hg}$ (32 $\mu \mathrm{g} \mathrm{L}^{-1}$ ) induced DNA damage and higher MNi frequencies in Mytilus galloprovincialis.

Cytotoxicity is defined as the pre-lethal changes and events which occur in cells prior to necrosis (Vasquez, 2012). Lesions to DNA and inefficient repair mechanisms are crucial in the unleashing of apoptosis (Roos and Kaina, 2006). Apoptosis is induced by the activation of intracellular proteases known as caspases (Boatright and Salvesen, 2003). Caspase-3 is an effector caspase in which both apoptosis pathways (intrinsic and extrinsic) converge. As shown in Fig. 3, significant increases $(p<0.05)$ with respect to the control group were observed in the specific activity of caspase3 at all exposure times in all test systems. This may be explained by the fact that, since ROS are produced, a change in membrane potential takes place with a consequent decrease in ATP production and an increase in calcium levels (Bondy and Campbell, 2001; Flora et al., 2003; Verstraeten et al., 2008; Yamamoto et al., 2002). Damage to DNA and increased cytosolic calcium can initiate the intrinsic pathway. In this pathway, cytochrome $\mathrm{c}$ and other apoptogenic proteins in the cytosol are released by the mitochondrion via the opening of mitochondrial pores regulated by the Bcl-2 family; this release can be ROS induced. Free cytochrome c binds to Apaf1 (apoptotic protease activating factor 1) forming a multimeric complex that recruits and activates procaspase-9. This activated caspase- 9 in turn activates the effector procaspase- 3 (Reed and Pellecchia, 2005). Caspase-3 is responsible for proteolytic cleavage of a wide range of cellular targets, leading ultimately to cell death; increased activity of this caspase is seen in apoptotic processes (Gulbins et al., 2003; Taylor et al., 2008). The metals analyzed in our study are reported to affect calcium homeostasis. Calcium is transported to the cell nucleus where it activates nucleases which induce DNA strand breaks and elicit cytotoxicity (Meneghini, 1997; Valko et al., 2005).

Antibodies against specific neoepitopes are used as markers for specific early events in apoptosis (O'Brien et al., 2001). In our study, anti-Fas $m A b$ was used as the positive control since it is an apoptosis inducer (Watanabe et al., 2004). A significant increase $(p<0.05)$ in caspase-3 activity was observed in the positive control with respect to the control group at all exposure times, while similar increases with respect to the positive control were observed at $12 \mathrm{~h}$ with $\mathrm{Fe}$ and the mixture; at $24 \mathrm{~h}$ with $\mathrm{Hg}$; at $48 \mathrm{~h}$ with $\mathrm{Al}, \mathrm{Fe}$ and the mixture; at $72 \mathrm{~h}$ with $\mathrm{Fe}$; and at $96 \mathrm{~h}$ with $\mathrm{Hg}$ and the mixture.

Apoptosis is characterized by cellular volume reduction, protein degradation, DNA fragmentation, chromatin condensation, blebbing of the cell surface and formation of apoptotic bodies (Thornberry, 1998).

One method used for in situ detection of DNA damage is the TUNEL assay, since it is able to detect cells in the initial stages of apoptosis and those in which morphologic changes, including apoptotic bodies, have already occurred (Gavrieli et al., 1992; Kylarová et al., 2002). Significant increases $(p<0.05)$ in this type of damage with respect to the control group are seen in Fig. 4 at all exposure times in all test systems ( $\mathrm{Al}, \mathrm{Fe}, \mathrm{Hg}$ and the mixture). This is consistent with our caspase- 3 activity results, since the metals analyzed induce DNA damage.

DNase I is an endonuclease that induces DNA fragmentation (Nagata, 2000). Significant increases $(p<0.05)$ in the percentage of TUNEL-positive cells were observed in the positive control relative to the control group at all exposure times (Fig. 4). However, significant decreases with respect to the positive control were found with $\mathrm{Al}$ and $\mathrm{Fe}(12,24,48$ and $96 \mathrm{~h}), \mathrm{Hg}(12,48,72 \mathrm{~h})$ and the mixture (12 and $24 \mathrm{~h}$ ).

Our cytotoxicity results are consistent with those of other authors, including García-Medina et al. (2011, 2013), who found an increase in the percentage of TUNEL-positive cells in Cyprinus carpio exposed to Al. Similarly, Voccia et al. (1994) described Hginduced cytotoxicity in Oncorhynchus mykiss while Dayeh et al. (2005) and Rau et al. (2004) reported Fe-induced cytotoxicity in the latter species and Poeciliopsis lucida, respectively.

Table 2 shows the correlation of metal concentrations with biomarkers of geno- and cytotoxicity; as can be seen, correlations exist at certain exposure times.

Most ecotoxicological studies focus on the effects of exposure to single contaminants, but aquatic organisms in a contaminated environment are usually exposed to a mixture of contaminants (De Zwart and Posthuma, 2005). Toxicity of the metal mixture depends on metal concentration and specific composition as well as duration of exposure of the fish (Vosylienè et al., 2003).

\section{Conclusions}

The metals $\mathrm{Al}, \mathrm{Fe}, \mathrm{Hg}$, and the mixture thereof induce cyto- and genotoxicity on blood of $C$. carpio exposed to the permissible concentrations for these metals in water for human use and consumption provided in the official Mexican norm NOM-127-SSA11994. The maximum permissible limits for these metals should be revised and updated since current values induce major damage on common carp and probably other aquatic species also, which, if consumed, could transfer these contaminants to humans.

\section{Conflict of interest}

The authors declare they have no actual or potential competing financial interests.

\section{Acknowledgments}

This study was made possible by financial support from the Consejo Nacional de Ciencia y Tecnología (CONACyT-Mexico, Project 181541) and the Programa para el Desarrollo Profesional Docente (PRODEP-México, Project 1039503).

\section{References}

Aisen, P., Enns, C., Wessling-Resnick, M., 2001. Chemistry and biology of eukaryotic iron metabolism. Int. J. Biochem. Cell Biol. 33, 940-959.

Allin, C.J., Wilson, R.W., 2000. Effects of pre-acclimation to aluminium on the physiology and swimming behaviour of juvenile rainbow trout (Oncorhynchus mykiss) during a pulsed exposure. Aquat Toxicol. 51, 213-224.

Al-Sabti, K., 1991. Handbook of Genotoxic Effects and Fish Chromosomes, first edition. J. Stefan Institute, Ljubljana, Slovenia.

Amador, F.C., Santos, M.S., Oliveira, C.R., 2001. Lipid peroxidation and aluminium effects on the cholinergic system in nerve terminals. Neurotox. Res. 3, 223-233.

Andreu, V., Gimeno-García, E., Pascual, J.A., Vazquez-Roig, P., Picó, Y., 2016. Presence of pharmaceuticals and heavy metals in the waters of a Mediterranean coastal wetland: potential interactions and the influence of the environment. Sci. Total Environ. 540, 278-286.

Avila-Pérez, P., Balcázar, M., Zarazúa-Ortega, G., Barceló-Quintal, I., Díaz-Delgado, C., 1999. Heavy metal concentrations in water and bottom sediments of a Mexican reservoir. Sci. Total Environ. 234, 185-196.

Berntssen, M.H., Aatland, A., Handy, R.D., 2003. Chronic dietary mercury exposure causes oxidative stress, brain lesions, and altered behaviour in Atlantic salmon (Salmo salar) parr. Aquat. Toxicol. 65, 55-72.

Beyersmann, D., Hartwig, A., 2008. Carcinogenic metal compounds: recent insight into molecular and cellular mechanisms. Arch. Toxicol. 82, 493-512.

Bhagwant, S., Bhikajee, M., 2000. Induction of hypochromic macrocytic anaemia in Oreochromis hybrid (Cichlidae) exposed to $100 \mathrm{mg} / \mathrm{l}$ (sublethal dose) of 
aluminium. Sci. Technol. 5, 9-20.

Boatright, K.M., Salvesen, G.S., 2003. Mechanisms of caspase activation. Curr. Opin. Cell Biol. 15, 725-731.

Bolann, B.J., Ulvik, R.J., 1990. On the limited ability of superoxide to release iron from ferritin. Eur. J. Biochem. 193, 899-904.

Bolognesi, C., Cirillo, S., 2014. Genotoxicity biomarkers in aquatic bioindicators. Zoology 60, 273-284.

Bolognesi, C., Landini, E., Roggieri, P., Fabbri, R., Viarengo, A., 1999. Genotoxicity biomarkers in the assessment of heavy metal effects in mussels: experimental studies. Environ. Mol. Mutagen. 33, 287-292.

Bombail, V., Aw, D., Gordon, E., Batty, J., 2001. Application of the comet and micronucleus assays to butterfish (Pholis gunnellus) erythrocytes from the Firth of Forth, Scotland. Chemosphere 44, 383-392.

Bondy, S.C., Campbell, A., 2001. Oxidative and inflammatory properties of aluminium: possible relevance in Alzheimer's disease. In: Exley, C. (Ed.), Aluminium and Alzheimer's Disease. The Science that Describes the Link, Elsevier, Amsterdam, pp. 311-321.

Bradford, M.M., 1976. A rapid and sensitive method for the quantitation of microgram quantities of protein utilizing the principle of protein-dye binding. Anal. Biochem. 72, 248-254.

Campanella, A., Rovelli, E., Santambrogio, P., Cozzi, A., Taroni, F., Levi, S., 2009. Mitochondrial ferritin limits oxidative damage regulating mitochondrial iron availability: hypothesis for a protective role in Friedreich ataxia. Hum. Mol. Genet. 18, 1-11.

Çavaş, T., Ergene-Gözükara, S., 2005. Induction of micronuclei and nuclear abnormalities in Oreochromis niloticus following exposure to petroleum refinery and chromium processing plant effluents. Aquat. Toxicol. 74, 264-271.

Cavas, T., Garanko, N.N., Arkhipchuk, V.V., 2005. Induction of micronuclei and binuclei in blood, gill and liver cells of fishes subchronically exposed to cadmium chloride and copper sulphate. Food Chem. Toxicol. 43, 569-574.

Cervantes, C., Moreno, R., 2010. Contaminación Ambiental por Metales Pesados Impacto en los Seres Vivos, first edition. AGT, Mexico City, Mexico.

Chan, H.M., Scheuhammer, A.M., Ferran, A., Loupelle, C., Holloway, J., Weech, S., 2003. Impacts of mercury on freshwater fish-eating wildlife and humans. Hum. Ecol. Risk Assess. 9, 867-883.

Chang, L.W., Magos, L., Suzuki, T., 1996. Toxicology of Metals, first edition. CRC, Boca Raton, FL.

Costa, S., Afonso, C., Cardoso, C., Batista, I., Chaveiro, N., Nunes, M.L., Bandarra, N.M., 2015. Fatty acids, mercury, and methylmercury bioaccessibility in salmon (Salmo salar) using an in vitro model: effect of culinary treatment. Food Chem. 185, 268-276.

Dayeh, V.R., Lynn, D.H., Bols, N.C., 2005. Cytotoxicity of metals common in mining effluent to rainbow trout cell lines and to the ciliated protozoan, Tetrahymena thermophila. Toxicol. Vitr. 19, 399-410.

De Boeck, G., Van der Ven, K., Meeus, W., Blust, R., 2007. Sublethal copper exposure induces respiratory stress in common and gibel carp but not in rainbow trout. Comp. Biochem. Physiol. C-Toxicol. Pharm. 144, 380-390.

De Zwart, D., Posthuma, L., 2005. Complex mixture toxicity for single and multiple species: proposed methodologies. Environ. Toxicol. Chem. 24, 2665-2676.

Driscoll, C.T., Han, Y.J., Chen, C.Y., Evers, D.C., Lambert, K.F., Holsen, T.M., Kamman, N. C., Munson, R.K., 2007. Mercury contamination in forest and freshwater ecosystems in the northeastern United States. BioScience 57, 17-28.

Dua, R., Gill, K.D., 2001. Aluminium phosphide exposure: implications on rat brain lipid peroxidation and antioxidant defence system. Pharmacol. Toxicol. 89, 315-319.

Exley, C., Pinnegar, K.J., Taylor, H., 1997. Hydroxyaluminosilicates and acute aluminium toxicity in fish. J. Theor. Biol. 189, 133-139.

Farina, M., Avila, D.S., da Rocha, J.B.T., Aschner, M., 2013. Metals, oxidative stress and neurodegeneration: a focus on iron, manganese and mercury. Neurochem. Int. 62, 575-594.

Fernández-Dávila, M.L. Razo-Estrada, A.C. García-Medina, S., Gómez-Oliván, L.M., Piñón-López, M.J., Ibarra, R.G., Galar-Martínez, M., 2012. Aluminum-induced oxidative stress and neurotoxicity in grass carp (Cyprinidae-Ctenopharingodon idella). Ecotox. Environ. Saf. 76, 87-92.

Flint, D.H., Smyk-Randall, E., Tuminello, J.F., Draczynska-Lusiak, B., Brown, O.R., 1993. The inactivation of dihydroxy-acid dehydratase in Escherichia coli treated with hyperbaric oxygen occurs because of the destruction of its Fe-S cluster, but the enzyme remains in the cell in a form that can be reactivated. J. Biol. Chem. 268, 25547-25552.

Flora, S.J., Mehta, A., Satsangi, K., Kannan, G.M., Gupta, M., 2003. Aluminum-induced oxidative stress in rat brain: response to combined administration of citric acid and HEDTA. Comp. Biochem. Physiol. C-Toxicol. Pharm. 134, 319-328.

Frenzilli, G., Nigro, M., Lyons, B.P., 2009. The Comet assay for the evaluation of genotoxic impact in aquatic environments. Mutat. Res. Rev. Mutat. Res. 681, 80-92.

Garcíal., DorronsoroC., 2005. Contaminación por metales pesados, in: Tecnología de Suelos. Universidad de Granada. Departamento de Edafología y Química Agrícola. 〈http://edafologia.ugr.es〉. (accessed 10.01.16).

García-Medina, S., Núñez-Betancourt, J.A., García-Medina, A.L., Galar-Martínez, M., Neri-Cruz, N., Islas-Flores, H., Gómez-Oliván, L.M., 2013. The relationship of cytotoxic and genotoxic damage with blood aluminum levels and oxidative stress induced by this metal in common carp (Cyprinus carpio) erythrocytes. Ecotox. Environ. Saf. 96, 191-197.

García-Medina, S., Razo-Estrada, C., Galar-Martinez, M., Cortéz-Barberena, E., Gómez-Oliván, L.M., Álvarez-González, I., Madrigal-Bujaidar, E., 2011. Genotoxic and cytotoxic effects induced by aluminum in the lymphocytes of the common carp (Cyprinus carpio). Comp. Biochem. Physiol. C-Toxicol. Pharm. 153, 113-118.

García-Medina, S., Razo-Estrada, A.C., Gómez-Oliván, L.M., Amaya-Chávez, A., Madrigal-Bujaidar, E., Galar-Martínez, M., 2010. Aluminum-induced oxidative stress in lymphocytes of common carp (Cyprinus carpio). Fish. Physiol. Biochem. 36, 875-882.

Gavrieli, Y., Sherman, Y., Ben-Sasson, S.A., 1992. Identification of programmed cell death in situ via specific labeling of nuclear DNA fragmentation. J. Cell Biol. 119 493-501.

González-González, E.D., Gómez-Oliván, L.M., Galar-Martínez, M., Vieyra-Reyes, P., Islas-Flores, H., García-Medina, S., Jiménez-Vargas, J.M., Razo-Estrada, C., PérezPastén, R., 2014. Metals and nonsteroidal anti-inflammatory pharmaceuticals drugs present in water from Madín Reservoir (Mexico) induce oxidative stress in gill, blood, and muscle of common carp (Cyprinus carpio). Arch. Environ. Contam. Toxicol. 67, 281-295.

Gulbins, E., Dreschers, S., Bock, J., 2003. Role of mitochondria in apoptosis. Exp. Physiol. 88, 85-90.

Gutiérrez, R.L., Rubio-Arias, H., Quintana, R., Ortega, J.A., Gutierrez, M., 2008. Heavy metals in water of the San Pedro River in Chihuahua, Mexico, and its potentia health risk. Int. J. Environ. Res. Public Health 5, 91-98.

Gutteridge, J.M.C., 1986. Iron promoters of the Fenton reaction and lipid peroxidation can be released from haemoglobin by peroxides. FEBS Lett. 201, 291-295.

Guzmán, F.T., González, F.J.A., Martínez, R.R., 2010. Implementing Lecane quadridentata acute toxicity tests to assess the toxic effects of selected metals ( $\mathrm{Al}, \mathrm{Fe}$ and Zn). Ecotox. Environ. Saf. 73, 287-295.

Halliwell, B., Aruoma, O.I., 1991. DNA damage by oxygen-derived species. Its mechanism and measurement in mammalian systems. FEBS Lett. 281, 9-19.

Halliwell, B., Gutteridge, J.M., 1990. The antioxidants of human extracellular fluids Arch. Biochem. Biophys. 280, 1-8.

Huang, X., 2004. Iron overload as a risk factor and molecular mechanism of carcinogenesis. Environ. Mol. Mutagen. 44 (206), 81A.

Huang, C.Y., Wu, C.H., Yang, J.I., Li, Y.H., Kuo, J.M., 2015. Evaluation of iron-binding activity of collagen peptides prepared from the scales of four cultivated fishes in Taiwan. J. Food Drug Anal. 23, 671-678.

Italia, K., Colah, R., Ghosh, K., 2015. Experimental animal model to study iron overload and iron chelation and review of other such models. Blood Cells Mol Dis. 55, 194-199.

Kadam, S.B., Shyama, S.K., Almeida, V.G., 2013. Evaluation of the in vivo genotoxic effects of gamma radiation on the peripheral blood leukocytes of head and neck cancer patients undergoing radiotherapy. Mutat. Res. Genet. Toxicol. Environ. Mutagen. 752, 42-46.

Kim, Y.A., Tarahovsky, Y.S., Yagolnik, E.A., Kuznetsova, S.M., Muzafarov, E.N., 2013. Lipophilicity of flavonoid complexes with iron (II) and their interaction with liposomes. Biochem. Biophys. Res. Commun. 431, 680-685.

Kylarová, D., Procházková, J., Mad'arová, J., Bartoš, J., Lichnovský, V., 2002. Comparison of the TUNEL, lamin $B$ and annexin $V$ methods for the detection of apoptosis by flow cytometry. Acta Histochem. 104, 367-370.

Li, M., Hu, C., Zhu, Q., Chen, L., Kong, Z., Liu, Z., 2006. Copper and zinc induction of lipid peroxidation and effects on antioxidant enzyme activities in the microalga Pavlova viridis (Prymnesiophyceae). Chemosphere 62, 565-572.

Lucho-Constantino, C.A., Álvarez-Suárez, M., Beltrán-Hernández, R.I., Prieto-García, F., Poggi-Varaldo, H.M., 2005. A multivariate analysis of the accumulation and fractionation of major and trace elements in agricultural soils in Hidalgo State Mexico, irrigated with raw wastewater. Environ. Int. 31, 313-323.

Medeiros, M.H.G., 2008. DNA damage. In: Konigsberg-Fainstein, M. (Ed.), Free Radicals and Oxidative Stress. Medical Applications. Manual Moderno, Mexico City, Mexico, pp. 122-124.

Mello-Filho, A.C., Meneghini, R., 1991. Iron is the intracellular metal involved in the production of DNA damage by oxygen radicals. Mutat. Res. Fundam. Mol. Mech. Mutagen. 251, 109-113.

Meneghini, R., 1997. Iron homeostasis, oxidative stress, and DNA damage. Free Radic. Biol. Med. 23, 783-792.

Møller, P., 2006. The alkaline comet assay: towards validation in biomonitoring of DNA damaging exposures. Basic Clin. Pharmacol. Toxicol. 98, 336-345.

Morel, F.M., Kraepiel, A.M., Amyot, M., 1998. The chemical cycle and bioaccumulation of mercury. Annu. Rev. Ecol. Syst. 29, 543-566.

Nagata, S., 2000. Apoptotic DNA fragmentation. Exp. Cell Res. 256, 12-18.

Neri-Cruz, N., Gómez-Oliván, L.M., Galar-Martínez, M., del Socorro Romero-Figueroa, M., Islas-Flores, H., García-Medina, S., Jiménez-Vargas, J.M., SanJuanReyes, N., 2015. Oxidative stress in Cyprinus carpio induced by hospital wastewater in Mexico. Ecotoxicology 24, 181-193.

NOM-127-SSA1-1994, 1994. Salud ambiental. Agua para uso y consumo humano. Límites permisibles de calidad y tratamientos a que debe someterse el agua para su potabilización. Secretaría de Salud. Diario Oficial de la Federación (20 June). Mexico City, Mexico.

O'Brien, M.A., Moravec, R.A., Riss, T.L., 2001. Poly (ADP-ribose) polymerase cleavage monitored in situ in apoptotic cells. Biotechniques 30, 886-891.

Oruç, E.Ö., Usta, D., 2007. Evaluation of oxidative stress responses and neurotoxicity potential of diazinon in different tissues of Cyprinus carpio. Environ. Toxicol. Pharmacol. 23, 48-55.

Pacyna, E.G., Pacyna, J.M., 2002. Global emission of mercury from anthropogenic sources in 1995. Water Air Soil Pollut. 137, 149-165.

Pérez, G., Vittori, D., Pregi, N., Garbossa, G., Nesse, A., 2005. Homeostasis del hierro. Mecanismos de absorción, captación celular y regulación. Acta Bioquim. Clin. Latinoam. 39, 301-314.

Rau, M.A., Whitaker, J., Freedman, J.H., Di Giulio, R.T., 2004. Differential 
susceptibility of fish and rat liver cells to oxidative stress and cytotoxicity upon exposure to prooxidants. Comp. Biochem. Physiol. C-Toxicol. Pharm. 137, 335-342.

Reed, J.C., Pellecchia, M., 2005. Apoptosis-based therapies for hematologic malignancies. Blood 106, 408-418.

Roos, W.P., Kaina, B., 2006. DNA damage-induced cell death by apoptosis. Trends Mol. Med. 12, 440-450.

Rosas, H., 2001. Estudio de la Contaminación por Metales Pesados en la Cuenca de Llobregat (Ph.D. Thesis). Universitat Politècnica de Catalunya, Barcelona, Spain.

Røyset, O., Rosseland, B.O., Kristensen, T., Kroglund, F., Garmo, Ø.A., Steinnes, E., 2005. Diffusive gradients in thin films sampler predicts stress in brown trout (Salmo trutta L.) exposed to aluminum in acid fresh waters. Environ. Sci. Technol. 39, 1167-1174.

Samanta, S., Dey, P., 2012. Micronucleus and its applications. Diagn. Cytopathol. 40, 84-90.

Santambrogio, P., Biasiotto, G., Sanvito, F, Olivieri, S., Arosio, P., Levi, S., 2007. Mitochondrial ferritin expression in adult mouse tissues. J. Histochem. Cytochem. $55,1129-1137$.

Sinha, S., Mallick, S., Misra, R.K., Singh, S., Basant, A., Gupta, A.K., 2007. Uptake and translocation of metals in Spinacia oleracea L. grown on tannery sludgeamended and contaminated soils: effect on lipid peroxidation, morpho-anatomical changes and antioxidants. Chemosphere 67, 176-187.

Taylor, R.C., Cullen, S.P., Martin, S.J., 2008. Apoptosis: controlled demolition at the cellular level. Nat. Rev. Mol. Cell Biol. 9, 231-241.

Tice, R.R., Agurell, E., Anderson, D., Burlinson, B., Hartmann, A., Kobayashi, H., Miyamae, Y., Rojas, E., Ryu, J.C., Sasaki, Y.F., 2000. Single cell gel/comet assay: guidelines for in vitro and in vivo genetic toxicology testing. Environ. Mol Mutagen. 35, 206-221.

Thornberry, N.A., 1998. Caspases: key mediators of apoptosis. Chem. Biol. 5, R97-R103.

Ullrich, S.M., Tanton, T.W., Abdrashitova, S.A., 2001. Mercury in the aquatic environment: a review of factors affecting methylation. Crit. Rev. Environ. Sci. Technol. 31, 241-293.

Valko, M., Morris, H., Cronin, M.T.D., 2005. Metals, toxicity and oxidative stress. Curr. Med. Chem. 12, 1161-1208.

Vasquez, M.Z., 2012. Recommendations for safety testing with the in vivo comet assay. Mutat. Res. Genet. Toxicol. Environ. Mutagen. 747, 142-156.
Verstraeten, S.V., Aimo, L., Oteiza, P.I., 2008. Aluminium and lead: molecular mechanisms of brain toxicity. Arch. Toxicol. 82, 789-802.

Villarini, M., Moretti, M., Dominici, L., Fatigoni, C., Dörr, A.J.M., Elia, A.C., Monarca, S., 2011. A protocol for the evaluation of genotoxicity in bile of carp (Cyprinus carpio) exposed to lake water treated with different disinfectants. Chemosphere $84,1521-1526$.

Vinodhini, R., Narayanan, M., 2009. The impact of toxic heavy metals on the hematological parameters in common carp (Cyprinus carpio L.). Iran. J. Environ. Health Sci. Eng. 6, 23-28.

Voccia, I., Krzystyniak, K., Dunier, M., Flipo, D., Fournier, M., 1994. In vitro mercuryrelated cytotoxicity and functional impairment of the immune cells of rainbow trout (Oncorhynchus mykiss). Aquat. Toxicol. 29, 37-48.

Vosylienè, M.Z., Kazlauskienė, N., Svecevičius, G., 2003. Effect of a heavy metal model mixture on biological parameters of rainbow trout Oncorhynchus mykiss. Environ. Sci. Pollut. Res. 10, 103-107.

Wang, S., Shi, X., 2001. Molecular mechanisms of metal toxicity and carcinogenesis. Mol. Cell. Biochem 222, 3-9.

Ward, R.J., McCrohan, C.R., White, K.N., 2006. Influence of aqueous aluminium on the immune system of the freshwater crayfish Pacifastacus leniusculus. Aquat. Toxicol. 77, 222-228.

Watanabe, M., Kitano, T., Kondo, T., Yabu, T., Taguchi, Y., Tashima, M., Umehara, H., Domae, N., Uchiyama, T., Okazaki, T., 2004. Increase of nuclear ceramide through caspase-3-dependent regulation of the "sphingomyelin cycle" in Fasinduced apoptosis. Cancer Res 64, 1000-1007.

Wittmann, G., 1981. Toxic metals. In: Förstner, U., Wittman, G. (Eds.), Metal Pollution in the Aquatic Environment. Springer-Verlag, Berlin, pp. 3-70.

Yadav, K.K., Trivedi, S.P., 2009. Sublethal exposure of heavy metals induces micronuclei in fish, Channa punctata. Chemosphere 77, 1495-1500.

Yamamoto, Y., Kobayashi, Y., Devi, S.R., Rikiishi, S., Matsumoto, H., 2002. Aluminum toxicity is associated with mitochondrial dysfunction and the production of reactive oxygen species in plant cells. Plant Physiol. 128, 63-72.

Yousef, M.I., 2004. Aluminium-induced changes in hemato-biochemical parameters, lipid peroxidation and enzyme activities of male rabbits: protective role of ascorbic acid. Toxicology 199, 47-57.

Zorov, D.B., Juhaszova, M., Sollott, S.J., 2014. Mitochondrial reactive oxygen species (ROS) and ROS-induced ROS release. Physiol. Rev. 94, 909-950. 